\title{
MENINGKATKAN KOMPETENSI GURU DALAM MENERAPKAN METODE BERVARIASI MELALUI SUPERVISI KLINIS KEPALA SEKOLAH DI SD NEGERI 101775 SAMPALI
}

\author{
Ida Eriani
}

Surel :gusni_sordiani@yahoo.com

\begin{abstract}
ABSTRAK
Penelitian ini bertujuan untuk meningkatkan kompetensi guru dalam menerapkan metode bervariasi supervise klinis kepala sekolah di SD Negeri 101775 Samapali. Dengan mengunakan metode pembelajaran yang bervariasi siswa dapat termotivasi dalam belajar untuk meningkatkan prestasinya. Berdasarkan hasil penelitian dapat disimpulkan bahwa dengan Supervisi Klinis dari kepala sekolah kompetensi guru meningkat dalam menerapkan Metode bervariasi dalam proses pembelajaran. Ini terbukti dari kondisi awal yang pada mulanya seluruh guru belum menerapkan Metode bervariasi (0\%) pada proses pembelajaran, pada siklus I pembuatan RPP (sesuai standar proses) 77,78\%, penerapan Metode bervariasi 44,44\%, sedangkan pada siklus II pembuatan RPP (sesuai standar proses) 100\%, penerapan Metode bervariasi 88,89\%.
\end{abstract}

Kata Kunci: Kompetensi Guru, Metode bervariasi, Supervisi Klinis

\section{PENDAHULUAN}

Tantangan pendidikan pada jenjang sekolah dasar di mana masa depan disadari akan semakin berat. Hal ini merupakan konsekuensi kemajuan dalam berbagai aspek kehidupan. Pertumbuhan penduduk dan peningkatan taraf hidup dengan sendirinya berdampak terhadap dunia pendidikan. Hal itu diantaranya ditunjukkan dengan meningkatnya aspirasi terhadap peningkatan pendidikan baik dalam arti perluasan kesempatan belajar maupun tuuntutan akan pendidikan yang bermutu. Untuk menjawab tuntutan tersebut, pendidikan pada jenjang Sekolah Dasar (SD) mau tidak mau harus segera melakukan upaya pengembangan dan inovasi secara skematik dan sistemik.

Oleh sebab itu, upaya inovasi pendidikan SD merupakan keharusan yang dilakukan setiap saat dan secara terus menerus. Apalagi selama ini banyak pihak yang masih kurang puas terhadap praktik pendidikan, maka selama itu pulalah akan ada upaya inovasi pendidikan. Upaya inovasi ini juga penting karena kita dihadapkan pada ketidakpastian masa depan dan ilmu pengetahuan dan teknologi yang begitu cepat. Inovasi pendidikan SD di sini berguna sebagai upaya lembaga pendidikan untuk menjembatani masa sekarang dengan masa datang. Selain itu, inovasi juga dikatakan sebagai jawaban atas persoalan internal dan eksternal dalam dunia pendidikan yang cendrung mengejar efesiensi dan efektifitas.

Sejak dilaksanakannya wajib belajar 9 tahun fungsi pendidikan SD telah mengalami perubahan yang mendasar. Pendidikan SD tidak lagi 

menjalankan fungsi terminal melainkan menjalankan fungsi transisional, artinya bagi setiap anak usia sekolah (6-13 tahun) menamatkan pendidikan di SD bukan lagi sebagai kondisi akhir dari pendidikan formal yang diharapkan melainkan sebagai tujuan antara karena setelah itu semua pihak harus membantu individu tamatan SD untuk melanjutkan pendidikan ke SLTP (Sekolah Lanjutan Tingkat Pertama) atau yang sederajat.

Tujuan pendidikan SD harus selalu mengacu pada tujuan pendidikan dasar serta memperhatikan tahap dan kareteristik perkembangan siswa, kesesuaiannya dengan lingkungan dan pembangunan daerah, arah pembangunan nasional serta memperhatikan perkembangan ilmu pengetahuan dan teknologi dan kehidupan umat manusia secara global.

Sekolah merupakan lembaga formal yang berfungsi membantu khususnya orang tua dalam memberikan pendidikan kepada anak-anak mereka. Sekolah memberikan pengetahuan, keterampilan dan sikap kepada anak didiknya secara lengkap sesuai dengan yang mereka butuhkan. Semua fungsi sekolah tersebut tidak akan efektif apabila komponen dari sistem sekolah tidak berjalan dengan baik, karena kelemahan dari salah satu komponen akan berpengaruh pada komponen yang lain yang pada akhirnya akan berpengaruh juga pada jalannya sistem itu sendiri. salah satu dari bagian komponen sekolah adalah guru.

Dalam upaya meningkatkan mutu pendidikan nasional, pemerintah khususnya melalui Depdiknas terus menerus berupaya melakukan berbagai perubahan dan pembaharuan sistem pendidikan kita. Salah satu upaya yang sudah dan sedang dilakukan, yaitu berkaitan dengan faktor guru. Lahirnya Undang-Undang No. 14 tahun 2005 tentang Guru dan Dosen dan Peraturan Pemerintah No. 19 Tahun 2005 tentang Standar Nasional Pendidikan, pada dasarnya merupakan kebijakan pemerintah yang didalamnya memuat usaha pemerintah untuk menata dan memperbaiki mutu guru di Indonesia. Michael G. Fullan yang dikutip oleh Suyanto dan Djihad Hisyam (2000) mengemukakan bahwa "educational change depends on what teachers do and think...". Pendapat tersebut mengisyaratkan bahwa perubahan dan pembaharuan sistem pendidikan sangat bergantung pada "what teachers do and think ". atau dengan kata lain bergantung pada penguasaan kompetensi guru.

Selama proses pembelajaran, kebanyakan guru belum memberdayakan seluruh potensi dirinya sehingga sebagian besar siswa belum mampu mencapai kompetensi individual yang diperlukan untuk mengikuti pelajaran lanjutan. Beberapa siswa belum belajar sampai pada tingkat pemahaman, siswa baru mampu mempelajari fakta, konsep, teori dan 
gagasan lainnya masih pada tingkat ingatan. Masih banyak guru belum dapat menggunakan dan menerapkan berbagai metode/strategi secara efektif dalam pemecahan masalah sehari-hari yang kontekstual. Kalau masalah ini dibiarkan dan berlanjut terus, lulusan sebagai generasi penerus akan sulit bersaing. Lulusan yang diinginkan bukan sekedar mampu mengingat dan memahami informasi tetapi juga harus mampu menerapkannya secara kontekstual melalui berbagai macam kompetensi. Rantai panjang yang menjadi masalah dalam dunia pendidikan harus diputuskan melalui paradigm pembelajaran, yaitu dari teacher centered (berpusat pada guru) beralih ke student centered (berpusat pada siswa). Dua pendekatan pembelajaran tersebut terdapat beberapa perbedaan yang penting, termasuk kerja guru, organisasi pembelajaran, jumlah siswa yang aktif dalam belajar dan bagaimana pembelajaran tersebut dinilai.

Pembelajaran atau pengajaran pada dasarnya merupakan kegiatan guru menciptakan situasi agar siswa belajar. Mengajar dan belajar merupakan kegiatan yang tidak dapat dipisahkan, ibarat sebuah mata uang yang bermata dua. Bagaimanapun baiknya guru mengajar, apabila tidak terjadi proses belajar pada para siswa, maka pengajarannya tidak baik/tidak berhasil. Sebaliknya meskipun cara atau metode yang digunakan guru sangat sederhana, tetapi apabila dapat mendorong siswa untuk belajar, maka pembelajaran tersebut akan berhasil.

$$
\text { Berdasarkan pengamatan }
$$
peneliti di SDN 101775 Sampali, terdapat beberapa kendala pada pembelajaran selama ini antara lain :

a. Siswa mengalami kesulitan dalam memahami konsep.

b. Siswa kurang aktif / siswa pasif dalam proses pembelajaran.

c. Siswa belum terbiasa untuk bekerja sama dengan temannya dalam belajar.

d. Guru kurang mengaitkan materi pembelajaran dengan kehidupan sehari-hari.

e. Hasil nilai ulangan / hasil belajar siswa pada pembelajaran rendah.

f. KKM tidak tercapai.

g. Pembelajaran tidak menyenangkan bagi siswa.

h. Kurangnya minat siswa terhadap pembelajaran

Di SDN 101775 Sampali guru berjumlah 17 orang yang terdiri dari: 12 orang guru kelas, 2 orang guru Agama Islam, 1 orang Agama Kristen Protestan, 2 orang guru Penjas/Kes. Dari seluruh guru di SDN 101775 Sampali hanya 7 orang yang membuat RPP sesuai Standar Proses (Permendiknas nomor 41 tahun 2007) dan belum ada guru yang menerapkan Metode bervariasi pada proses pembelajaran di kelasnya.

Sebagai kepala sekolah, peneliti melihat pembelajaran menjadi kurang efektif karena banyak para guru hanya cenderung mengedepankan aspek intelektual 
dan mengesampingkan aspek pembentukan karakter di dalam RPP (Rencana Pelaksanaan Pembelajaran). Hal ini disebabkan para guru dalam membuat RPP belum berorientasi pada Permendiknas nomor 41 tahun 2007. Namun peneliti ingin mengubah hambatan tersebut menjadi sebuah kekuatan dalam pengelolaan kegiatan belajar mengajar yang efektif dan efisien sehingga nantinya akan mendapatkan hasil yang memuaskan.

\section{METODE PENELITIAN}

Penelitian ini tergolong penelitian tindakan sekolah, dengan empat langkah pokok yaitu: perencanaan tindakan, pelaksanaan tindakan, pengamatan (Observasi), dan Refleksi.

Dalam upaya memecahkan
masalah tentang rendahnya
kompetensi guru dalam penerapan
metode bervariasi, maka akan
dilakukan tindakan berupa: 1.
Supervisi Klinis terhadap guru-guru SDN 101775 Sampali. 2. Penerapan metode bervariasi oleh guru-guru SDN 101775 Sampali.

\section{HASIL PENELITIAN DAN PEMBAHASAN}

Hasil pengamatan pada siklus satu dapat dideskripsikan berikut ini: Pengamatan dilaksanakan Senin, 2 September 2015 terhadap 2 orang guru, Selasa, 3 September 20152 orang guru, dan Rabu, 3 September 20152 orang guru Semuanya menyusun RPP, tapi masih ada guru membuat RPP-nya tidak sesuai dengan Standar Proses. Dan ada beberapa orang guru yang RPP-nya dalam langkah-langkah pembelajaran tidak menggambarkan penerapan metode bervariasi. Untuk komponen penilaian hasil belajar, dapat dikemukakan sebagai berikut:

1) Satu orang tidak melengkapinya dengan teknik dan bentuk instrumen; 2) satu orang tidak melengkapinya dengan teknik, bentuk instumen, soal, pedoman penskoran, dan kunci jawaban orang tidak melengkapinya dengan teknik, pedoman penskoran, dan kunci jawaban; 3) Satu orang tidak melengkapinya dengan soal, pedoman penskoran, dan kunci jawaban. A) Satu orang tidak melengkapinya dengan pedoman penskoran dan kunci jawaban. B) Dalam dikusi kelompok sering terjadi perdebatan tentang beberapa hal. Hasil pengamatan menunjukkan ternyata ada 2 orang guru yang sangat bijak mensikapi perbedaan pendapat tersebut yaitu dengan siap menerima saran dan usulan teman lain yang dirasa bermanfaat untuk perbaikan.

Dari sisi keaktifan guru, masih ada beberapa orang guru yang nampak pasif dalam kerja kelompok. Beberapa guru saling adu argumen untuk mempertahankan pendapatnya yang dianggap benar. Hal ini menunjukkan adanya motivasi yang tinggi dalam mewujudkan RPP yang baik dan benar.

Hasil refklesi siklus I menunjukkan $100 \%$ guru telah berhasil memahami pembuatan RPP 
sesuai Standar Proses, 5 orang guru dengan mantap menyampaikan pendapatnya bahwa mengajar tanpa RPP akan menyebabkan PBM tidak terarah sehingga setelah seleasi bimbingan mereka bertekad untuk selalu menyusun RPP yang sesuai Standar Proses pada setiap akan melaksanakan PBM.

Pada waktu peerteaching juga menunjukkan peningkatan yang pada awalnya belum ada guru yang menerapkan metode bervariasi pada siklus pertama ini sudah $66,67 \%$ (4 orang guru) dari subjek penelitian yang sudah mampu menerapkan metode bervariasi dalam proses pembelajaran. a) Selanjutnya kepala sekolah melakukan supervisi klinis untuk lebih meningkatkan kompetensi guru dalam menerapkan metode bervariasi di kelasnya masing-masing.

Pengamatan dilaksanakan pada minggu pertama sampai dengan minggu keempat bulan September 2015, terhadap 6 orang guru. Pada siklus kedua ini pengamatan fokus terhadap kompetensi guru dalam penerapan metode bervariasi dalam Proses Pembelajaran. Dari pengamatan yang dilakukan peneliti terhadap enam orang guru tersebut diperoleh data sebagai berikut: 1) Satu orang guru masih belum memotivasi siswa dalam kegiatan awal pembelajaran, namun sudah mulai nampak melibatkan siswa dalam pembelajaran; 2) Satu orang guru belum menyampaikan tujuan pembelajaran dalam kegiatan awal; 3) Satu orang guru masih belum memanfaatkan media yang dibuatnya secara maksimal sehingga pembelajaran masih terkesan konvensional (teacher centerd); 4) Enam orang orang guru yang menjadi subjek penelitian sudah menerapkan metode bervariasi dalam proses pembelajaran di dalam kelasnya.

\section{Pembahasan}

Penelitian Tindakan Sekolah dilaksanakan di SD NEGERI 101775 SAMPALI Kecamatan Percut Sei Tuan Kabupaten Deli Serdang yang terdiri atas 17 orang guru, namun yang menjadi subjek penelitian ini hanya 6 orang guru, yaitu guru kelas 4 s.d 6 yang masing-masing 2 orang guru VI, 2 orang guru kelas V, dan 2 orang guru kelas IV dilaksanakan dalam dua siklus. Keenam guru yang menjadi subjek penelitian ini menunjukkan sikap yang baik dan termotivasi dalam menerapkan metode bervariasi dalam kelasnya. Hal ini peneliti ketahui dari hasil pengamatan pada saat melakukan wawancara pada saat kepala sekolah melakukan supervisi klinis dalam penerapan metode bervariasi pada proses pembelajaran.

Selanjutnya dilihat dari kompetensi guru dalam menerapkan metode bervariasi pada proses pembelajaran, terjadi peningkatan dari siklus 1 ke siklus 2 .

a. Enam orang guru telah melibatkan siswa dalam berbagai kegiatan yang mengembangkan pemahaman dan kemampuaan 
mereka dengan penekanan pada belajar melalui berbuat.

b. Enam orang guru yang menjadi subjek penelitian sudah menggunakan berbagai alat bantu dan berbagai cara dalam membangkitkan semangat termasuk menggunakan lingkungan sebagai sumber belajar untuk menjadikan pembelajaran menarik, menyenangkan, dan cocok bagi siswa.

c. Keenam orang guru sudah mengatur kelas dengan membuat pajangan kelas, bahan belajar yang lebih menarik, dan menyediakan "pojok baca".

d. Keenam orang guru sudah menerapkan cara mengajar yang lebih kooperatif dan interaktif, termasik cara belajar kelompok.

e. Lima orang guru mendorong siswa untuk menemukan caranya sendiri dalam pemecahan suatu masalah, untuk mengungkapkan gagasannya, dan melibatkan siswa dalam menciptakan lingkungan sekolahnya.

f. Keenam orang guru sudah menggunakan metode bervariasi dalam proses pembelajaran dalam kelasnya.

Dari uraian di atas secara keseluruhan dapat dilihat dalam grafik di bawah ini:
Grafik Hasil Praktek Membuat RPP Dan Penerapan Pendekatan Metode Bervariasi Pada Pbm Siklus 1 Dan 2.

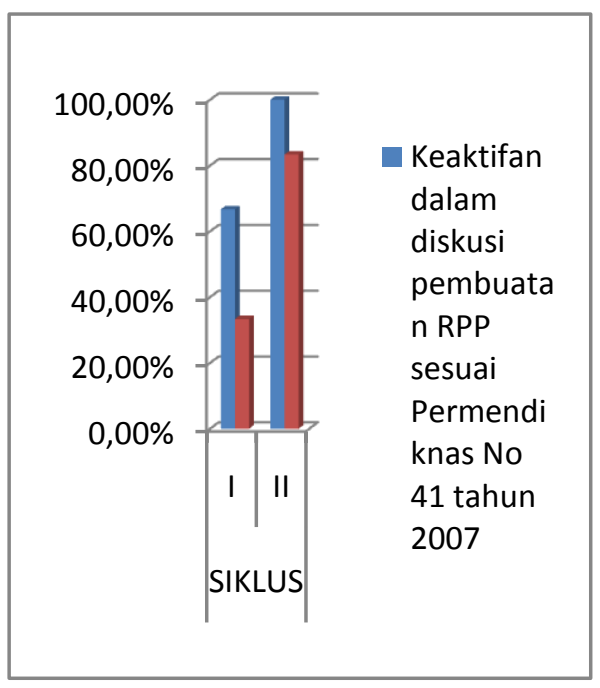

Berdasarkan pada Grafik Keaktifan dalam diskusi membuat RPP pada siklus 1 mengalami kenaikan dari 66,67\% menjadi $100 \%$ peningkatannya adalah $33,33 \%$ sedangkan kemampuan dalam menerapkan metode bervariasi pada PBM pada siklus 1 mengalami kenaikkan 50\%, yang pada siklus pertama hanya 2 orang guru $(33,33 \%)$ menjadi 5 orang guru $(83,33 \%)$.

\section{SIMPULAN}

Kesimpulan dari penelitian ini didasarkan pada hasil temuan penelitian ini, bahwa melalui Supervisi Klinis yang dilakukan kepala sekolah terhadap guru-guru SDN 101775 Sampali memberikan dampak yang positif di mana para guru meningkat kompotensinya dalam menerapkan metode bervariasi dalam proses pembelajaran. Hal ini 
Ida Eriani : Meningkatkan Kompetensi Guru ....

terlihat dari meningkatnya kemampuan guru-guru secara umum di SDN 101775 Sampali dalam penerapan metode bervariasi, khususnya enam orang guru yang menjadi subjek penelitian ini.

Berdasarkan penelitian tindakan sekolah ini, ada beberapa hal yang perlu disampaikan antara lain:

a. Bahwa dengan supervisi Klinis dari kepala sekolah guru-guru dapat meningkatkan kompetensinya

b. Melalui penerapan metode bervariasi oleh guru-guru dapat meningkatkan hasil belajar siswa.

c. Kemampuan guru dalam menerapkan metode bervariasi dalam proses pembelajaran salah satu hal yang harus dimiliki oleh setiap guru.
DAFTAR RUJUKAN

Anita, W. Sri, dkk. 2010. Strategi Pembelajaran. Jakarta:

Universitas Terbuka.

Dahlan, M. Djawad, dkk. 2007. Pendidikan dan Pelatihan. Bandung: TIPP FIP - UPI.

Peraturan Pemerintah Nomor 22 tahun 2006 tentang Standar Isi untuk Satuan Pendidikan Dasar dan Menengah.

Peraturan Menteri Pendidikan Nasional Nomor 41 tahun 2007 tentang Standar Proses untuk Satuan Pendidikan Dasar dan Menengah.

Sudrajat, Akhmad. 2008. Pendekatan Pembelajaran. Jakarta: Universitas Terbuka.

Sudjana, Djuju. 2007. Bimbingan dan Konseling. Bandung: TPIP FIP - UPI.

Syah, Muhibbin. 2006. Psikologi Pendidikan. Bandung: Penerbit Remaja Rosda Karya 